\title{
Dunmisk and glass-making in Early Christian Ireland
}

\section{JULIAN HENDERSON \& RICHARD IVENS*}

Dunmisk fort (Co. Tyrone), in Northern Ireland, has produced the first evidence recognized in early medieval Europe for the making/modification of glass using primary raw materials. Going beyond the evidence for glass-working - the softening of glass to form and decorate artefacts - a series of sophisticated industrial processes can be identified, and shows that not all glass was imported to Early Christian Ireland.

\begin{abstract}
Dunmisk
The Fairy Hill of Dunmisk (H 628706) is situated on the boundary of Dunmisk townland, some 2 miles south of the small town of Carrickmore in Co. Tyrone. The site, a prominent steep-sided glacial hill rising to c. $600 \mathrm{ft}$ above sea level, commands remarkable views to the north across the plain of Omagh, and to the east and west along the Camowen valley. The south side of the hill slopes gently down to a small, now largely overgrown and rather swampy lough. This area forms a natural sheltered enclosure, bounded by a steep gorge and a massive glacial ridge.

Before excavation nothing was known of the history of the site, although there is a local tradition that King James II and his army camped there in 1690 (no evidence to support this view was found). Archaeological attention was originally drawn to the hill by the staff of the first Ordnance Survey, who dubbed it a fort. Although excavation has shown this to be a misnomer, it is an understandable error in view of the dún (fort) element of the place-name, the commanding situation of the site and the quite obviously artificial nature of the hill's summit. The absolutely flat hill-top, emphasized by a terrace just below its crest, marks Dunmisk as an archaeological site, and makes it stand out so clearly, even against the higher hills to the south.
\end{abstract}

A series of excavations was carried out by one of us (RI) between 1984 and 1986 on behalf of the Historic Monuments and Buildings Branch of the Department of the Environment (for Northern Ireland) when the site was threatened by a proposed gravel quarry. As a result of the excavations the plans for quarrying were abandoned. A detailed account will be published elsewhere (Ivens in press).

A scatter of redeposited flints and other finds indicate that the site was utilized, if not occupied, during the Neolithic, Bronze and Iron Ages. During the Early Christian period the hill-top was sculpted into the distinctive form which survives to this day. Originally, we think the hill had a somewhat domed and gently sloping top and was certainly occupied by an Early Christian community. A terrace was cut around the circumference of the hill, and the material thrown inwards to form a flat area bounded by a steep drop down to the level of the terrace. By the end of the Early Christian period the site appears to have been abandoned, or at least used only for agricultural purposes.

\section{Functional areas}

The evidence for Early Christian activity at Dunmisk of 6th-10th-century date is summarized in FIGURE 1. The whole of the central and southeastern part of the site was occupied by a large cemetery. The remains of a substantial 
DUNMISK FORT.

CARRICKMORE, CO. TYRONE
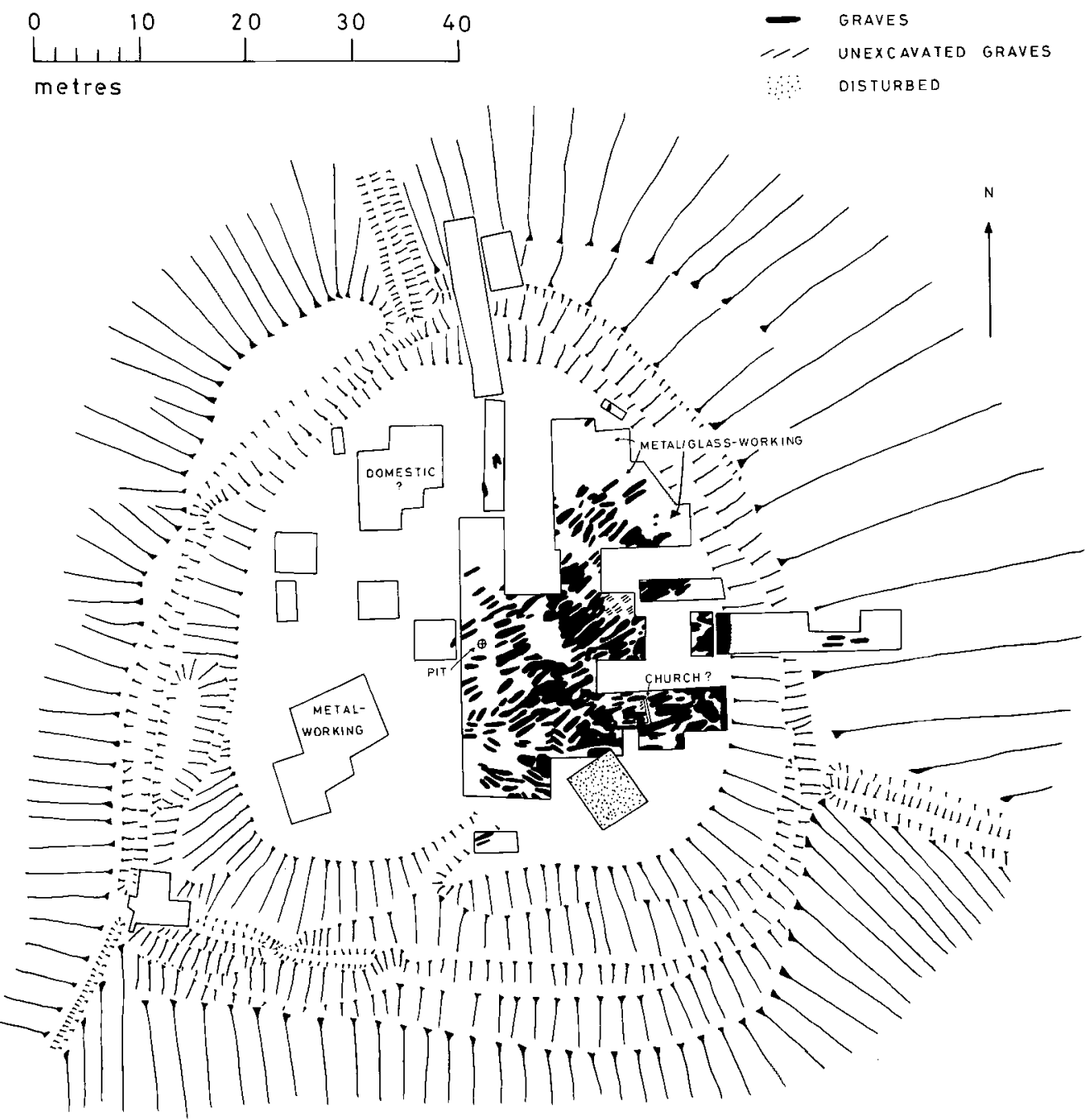

1 The location and excovated areas of Dunmisk, Co, Tyrone. 


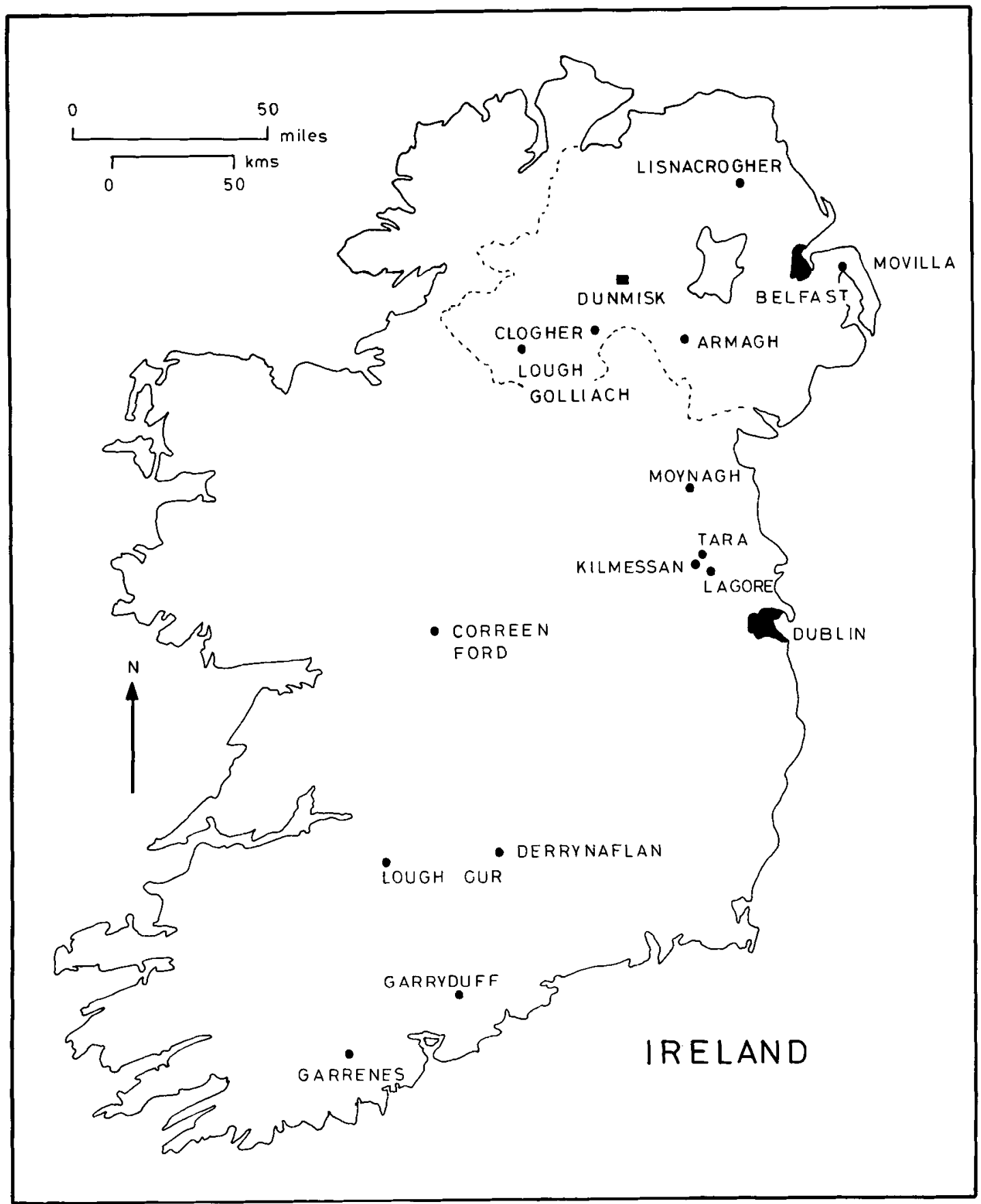

FIGURE 2. The location of sites mentioned in the text. 
timber building (probably a church) were found in the southeast corner. The northeast quadrant was largely occupied by the debris associated with glass-and metal-working, though was also used periodically for burials. The greater part of the southwest quadrant also seems to have been used for industrial purposes. The northwest quadrant yielded a complex of rather different features that might be interpreted as having a domestic function. It appears that a highly planned settlement was deliberately arranged into four quadrants, each with a distinct function, and this allows a convenient means of discussing the industrial, domestic and religious functions of the site.

The southwest quadrant seems to have been used only for the construction and firing of a series of small furnaces - judging from the slag found - probably for iron-smelting. Perhaps the potential fire risk to timber and thatched structures is sufficient reason to separate such activities from the rest of the settlement. Other than considerable quantities of slag and occasional fragments of fired clay, no artefacts were recovered from this part of the site.

The distinctive remains in the northwestern part of the site consisted largely of a very large number of stake-holes together with a hearth complex. The stake-holes, forming no obvious pattern, would appear to represent numerous rebuildings of more or less temporary structures. Given the large proportion of the site that was excavated, this is the only area which could have housed a resident community.

A burial-ground covered almost all of the central and southeastern parts of the site, with some 500 graves packed into this area. The level of bone survival was poor, and virtually no grave goods were found - only an amber bead and a single ring-pin. Distinct burial patterns were observed within the cemetery. In the central areas well-spaced graves were arranged in lines running southwest/northeast and seem to have been focused around a large pit: this might once have held a cross or pillar stone. To the south and east of the central area, the graves, still roughly orientated southwest/northeast, were packed very densely and arranged in distinct lines so that the head of each more easterly burial was cut into the foot of its western predecessor. This resulted in chains of graves dug 'head-to-toe' comparable to some at Yeavering (Hope-Taylor 1977: 250-52). Within the eastern end and just to the east of the probable church, were discovered a number of very large and elaborate graves, several marked with kerb stones or with a capping of white quartzite pebbles.

\section{The principal industrial area}

The activities in the northeast quadrant of the site were dominated by industrial or craft processes, although a number of burials both preand post-dated the industrial activity. The whole area was covered with black, ash- and charcoal-rich deposits. Two features are worthy of especial mention. The first consisted of a series of hearths built one on top of another: these were simple hollows scraped into the ground, the earliest stone-lined. The fill of the uppermost hearth overflowed its edges and merged gradually into the surrounding layer of ash and charcoal. It was from the fill of this hearth that the majority of the glass artefacts were recovered. A short distance away, also sealed by layers of ash and charcoal, lay the second noteworthy feature, a mound of sandy earth capped by pink-burnt clay and containing several small charcoal-filled hearths or furnaces. Fragments of metal-working crucible were commonly found throughout the layers of ash and charcoal and sometimes even within the grave-fills, as was a glass rod.

Little survived of the actual industrial complex. The quantities of ash and charcoal suggest that manufacture was either short-lived but on a considerable scale, or on a lesser scale over a considerable time. We favour the latter, particularly given the evidence for the rebuilding of the hearths.

Apart from the glass, crucible and slag discussed below, a large number of mould fragments and a few pieces of tuyere were also recovered. The mould fragments, all composed of the typical sandy and friable clay, very rarely survived well enough for their original form to be determined. However, evidence was found of at least one multi-piece mould, with a rodshaped core (13 mm long and $7 \mathrm{~mm}$ in diameter) and an outer case with an internal diameter of $9 \mathrm{~mm}$. This would have allowed the casting of a hollow tube with an external diameter of $9 \mathrm{~mm}$, in metal $1 \mathrm{~mm}$ thick. Therefore it seems likely that composite artefacts of glass and metal (copper alloy) were being made at Dunmisk.

It would seem that the summit of Dunmisk 
Hill in the Early Christian period held a small church or shrine, a large graveyard, two areas of industrial activity and a domestic area. We therefore suggest it was a small monastic community. The number of burials, and the fact that skeletons of all ages and both sexes were recovered, suggest that this community also provided the surrounding area with a graveyard, presumably with other ecclesiastical functions and possibly with manufactured products (pace Scott 1990: 96-7). It also seems likely that use as a graveyard continued after its monastic abandonment, judging by the number of graves cut through the remains of the suggested church or shrine, and indeed into the northeastern industrial complex.

If so, we see the large elaborate graves as those of the abbots, or of ecclesiastics, or even of important laymen; certainly they seem to belong to a high social class. The spaced central burials would belong to a slightly lower class, and the packed 'head-to-toe' burials to a general population, perhaps in specific groupings; do the lines represent particular kin or clan burials?

A problem for any Early Christian Irish site is its precise dating. At Dunmisk the few finds suggest occupation in the later Early Christian period (6th-10th centuries) though these cannot be closely dated. A series of radiocarbon determinations would tend to confirm this (see TABLE 1), though the samples were all taken from charcoal spreads which accumulated over an uncertain period of time; the type and age of the carbonized plant source is also uncertain.
Therefore these determinations cannot be used for close dating of the archaeological deposits. In fact, almost any of the activities on the site, apart from the glass-making and working and other contemporary industries could have taken place at any time during the second half of the 1st millennium AD.

The best dated parallel for the production of glass bichrome cables is in Viking Scandinavia in the early 8th century at the sites of Åhus, Scania and Ribe, Jutland (Callmer \& Henderson 1991; Bencard \& Jørgensen 1990). A ${ }^{14} \mathrm{C}$ determination of $1320 \pm 80$ (HAR 6829) was made on a sample taken from the general ash and charcoal spread associated with the glassworking. It therefore seems likely that the glassmaking at Dunmisk was approximately contemporary with that in early Viking Scandinavia. There is, however, clear evidence of an earlier phase of Early Christian occupation of the site.

The Tripartite Life of Patrick written in about $900 \mathrm{AD}$ refers to a now lost church called Domnach Mescáin (the Brewer's church). Could Dunmisk be a corruption of Domnach Mescáin (dún for domnach, that is church), and this hill-top be the site of a forgotten foundation dating back even as far as the 5th century $\mathrm{AD}$ (Hamlin pers. comm.)?

\section{The evidence for glass-working}

There is an important distinction to be made between the evidence for glass-working and glass-making. Dunmisk is one of a number of Early Christian Irish sites that has produced evidence for glass-working, that is, simply heat-

\begin{tabular}{|c|c|c|c|c|c|c|}
\hline $\begin{array}{l}1 \\
\text { lab. no. }\end{array}$ & $\begin{array}{l}2 \\
\text { context }\end{array}$ & $\begin{array}{l}3 \\
\text { uncalibrated } \\
\text { determination } \\
\text { b.p. }\end{array}$ & $\begin{array}{l}4 \\
\text { calibrated } \\
\text { date } \\
\text { AD }\end{array}$ & $\begin{array}{l}5 \\
+E M\end{array}$ & $\begin{array}{l}6 \\
+A L\end{array}$ & $\begin{array}{l}7 \\
+\mathbf{E M} / \mathbf{A L}\end{array}$ \\
\hline HAR-6833 & 7.45 & $1480 \pm 100$ & $380-690 \mathrm{AD}$ & $380-690 \mathrm{AD}$ & $450-820 \mathrm{AD}$ & $450-820 \mathrm{AD}$ \\
\hline HAR-6832 & $33.9 / 10$ & $1270 \pm 80$ & $630-900 \mathrm{AD}$ & $380-1180 \mathrm{AD}$ & $690-1040 \mathrm{AD}$ & $460-1300 \mathrm{AD}$ \\
\hline HAR-6831 & 2.94 & $1230 \pm 80$ & $650-980 \mathrm{AD}$ & $410-1230 \mathrm{AD}$ & $710-1120 \mathrm{AD}$ & $470-1350 \mathrm{AD}$ \\
\hline HAR-6830 & 7.36 & $450 \pm 80$ & $1310-1640 \mathrm{AD}$ & $1180-\bmod A D$ & $1370-1780 \mathrm{AD}$ & $1260-\bmod \mathrm{AD}$ \\
\hline HAR-6829 & 36.16 & $1320 \pm 80$ & $600-890 \mathrm{AD}$ & $260-1160 \mathrm{AD}$ & $660-1030 \mathrm{AD}$ & $340-1280 \mathrm{AD}$ \\
\hline HAR-6828 & 23.30 & $1260 \pm 70$ & $650-900 \mathrm{AD}$ & $460-1160 \mathrm{AD}$ & $710-1040 \mathrm{AD}$ & $500-1280 \mathrm{AD}$ \\
\hline
\end{tabular}

The calibrations in columns 4-7 were prepared by R. Warner of the Ulster Museum. Column 4 lists the $95 \%$ probability date ranges calibrated after Stuiver \& Pearson (1986). Column 5 applies an 'Error Multiplier' to the standard deviation (as in Scott et al. 1983).

Column 6 applies an estimated age-lapse of 200 years for potential 'old wood effect' (using the method of Warner 1989). Column 7 applies both the 'Error Multiplier' and 'old wood' correction factors.

TABLE 1. Radiocarbon determinations for Dunmisk (Harwell Laboratory). 
ing glass until sufficiently soft to manufacture glass bosses, millefiori rods, cables and beads. The glass objects found at Dunmisk were a failed blue glass stud, failed glass beads, monochrome glass rods, a probable failed bichrome cable, and three segments of millefiori rods (see FIGURE 3). All provide evidence for glassworking on the site.

Similar evidence for glass-working has been found on other Irish sites (see TABLE 2).

The large opaque sealing-wax red block of glass from Tara or Kilmessan, Co. Meath (Ball \& Stokes 1893; Youngs 1989: 201) is important in its own right and deserves detailed consideration. It lacks a firm archaeological context and contains high levels of lead oxide and cuprous oxide (Ball \& Stokes 1893: 280-81) - both its colour and composition are found in glass used in various ways as far back as C. $600 \mathrm{BC}$ in Europe and Britain (Bimson 1987: 169 and Henderson 1989a: 67). Its composition and colour is quite different from the dull brownish-red glass used

site

Scotch St,

Co. Armagh

Cathedral Hill,

Co. Armagh

Garranes,

Co. Cork

Garryduff I,

Co. Cork

Movilla Abbey,

Co. Down

Carraig Aille II,

Lough Gur,

Co. Limerick

Lough Golliach

crannog,

Co. Fermanagh

Lagore crannog,

Co. Meath

Moynagh Lough,

Co. Meath

Tara or Kilmessan,

Co. Meath

\section{evidence}

bichrome cables,

monochrome rod,

pan for ?heating glass

monochrome rods,

glass-bearing crucibles

millefiori rod, plaque,

monochrome rods, possible

'enamel'-bearing crucible,

copper alloy tube for holding millefiori

flattened sphere,

possible unfinished stud,

possible pan for heating glass

bichrome cable,

twisted monochrome rods, glass globules

'flattened teardrop'

large piece of glass

in an 'unmanufactured state'

monochrome rods, millefiori rod,

9 stud moulds ( 2 with

glass adhering),

possible pan for heating glass

Glass rod, block of yellow glass

Large block of sealing-

wax-red glass for the decoration of Early Christian glass beads from Moynagh Lough, Co. Meath and Clogher, Co. Tyrone (Henderson unpublished data). Those glasses contain significantly lower lead and copper oxide levels than in the 'Tara' block, and, in addition, their elevated magnesium and potassium oxide levels clearly ally them to the composition of Roman reddish enamels, to some glass tesserae dating to after the 2nd century $A D$ and to many Anglo-Saxon and 8th-century Scandinavian brownish-red glasses (Henderson 1990 and Callmer \& Henderson 1991). There is therefore a possibility that the 'Tara' block dates to the end of the 1st millennium BC or earlier, and not to the Early Christian period at all.

If glasses attached to Early Christian metal surfaces were found to have the same chemical characteristics as the Tara block, one could suggest that the block had been used for Early Christian inlay and formed part of a technological continuity in the use of red glass dating back

\section{references}

Lynn 1988

Youngs 1979: 203-204

Gaskell \& Harper 1984

Ó Ríordáin 1941-2: 118-21

Youngs 1979: 202

O'Kelly 1962: 72-4, 77

Henderson 1984

Ó Ríordáin 1949:

figure 19, nos. 19-20

Wakeman 1889: 106

Hencken 1950: 129, 130, 132

Youngs 1979: 202-3, 205-6

Haseloff 1990: plate 127

Youngs 1989: 201, 205

Ball \& Stokes 1893

Youngs 1989: 201

TABLE 2. Evidence and possible evidence for glass-working in Early Christian Ireland (6th-10th centuries $A D$ ). 
to the European early Iron Age. That 'Celtic' sealing-wax-red glass was used in 7th-century AD England is in no doubt. Both 'Celtic' sealingwax-red and 'Roman' brownish-red glasses were used for embedding and in the millefiori respectively in the decoration of a hanging bowl found in the Sutton Hoo ship burial of c. $625 \mathrm{AD}$ (Bimson 1978; 1983). The sealing-wax red Taratype glass cannot be used for enamelling because it loses its red colour when ground up, applied and then re-heated (Bimson 1987: 169); its use for decoration on Irish metalwork is in the form of lumps which have been softened and quickly pressed onto a prepared surface in a reducing atmosphere. (A second sealing-wax red lump from Fish Street Hill, London is in the British Museum.) It is significant that the brownish-red glass used in the Sutton Hoo millefiori conforms to the chemical compositions of many of the Scandinavian 8th-century specimens of brownish-red glass used in millefiori analysed to date (Henderson unpublished data; Callmer \& Henderson 1991). Sealing-waxred glass was used for the decoration of Irish Early Christian metalwork; it should be noted (perhaps not surprisingly) that the available evidence shows that the red glass used for Early Christian metal decoration and for glass bead making probably had different sources, and this suggests that the organization of the industries was therefore somewhat different.

Ceramic crucibles and heating trays, not unusual on Irish Early Christian sites, are commonly taken as evidence for small-scale industrial activity. There are, for instance, definite examples of crucibles used for heating glass ready to shape into glass artefacts (see TABLE 2). It has been suggested that the red vitreous accretions found in heating trays are the result of red enamel-working; when scientifically investigated, these accretions (such as those from Moynagh Lough) have been found to be fuel-ash-slags from metal-working (particularly copper-alloy production) and not of the diagnostic composition of red glasses and enamels. These slags are formed from an interaction between silica present in the crucible fabric and plant ash (the alkali source) in the environment of the furnace or hearth (Biek \& Bayley 1979); $c f$. Warner in Youngs 1989: 186. No red enamel has yet been scientifically identified in Early Christian heating trays. The fragments of crucible from Garranes ringfort, Co.
Cork on which red enamel droplets are claimed to be present (Ó Ríordáin 1941-2: 121) should be chemically analysed before this identification can be accepted. Definite glass-working crucibles, such as those from Cathedral Hill, Armagh, bear a thin layer of glass (Gaskell \& Harper 1984: 146, figure 19, no. 113 and a further unpublished example) but there is little evidence for interaction between the inner face of the crucible wall and the glass and no evidence of relic primary glass raw materials, both features of Dunmisk crucible fragments (see below). It has been suggested that metal 'heating trays' such as the plate from Scotch Street, Armagh and the pan or ladle from the river Suck at Correen, Co. Roscommon (Webster in Youngs 1989: 204) were used for heating glass, but they would only have been used for softening the glass slightly in order to shape it; a more closed vessel shape (a crucible) would have been necessary to heat glass until it was fluid. The heating tray from 8th-century Ribe, Jutland (Bencard et al. 1979: figure 15) has been accepted as part of the evidence for bead making there, and such a tray has been incorporated in successful experimental bead making (Gam 1991). Working of glass using Irish practices occurred outside Ireland. Evidence for the mid-7th- to 8th-century manufacture of glass studs in moulds has been found on Iona (Graham-Campbell 1981: 24-5), an Irish monastic foundation in the Kingdom of Dalriada.

\section{The evidence for glass-making}

The evidence for glass-making in crucibles can be clearly distinguished from that produced by glass-working. Glass-working crucibles have a relatively clean layer of glass lying on the inner face, with no evidence for the fusion of raw materials and little or none for the interaction between the glass and the crucible face. The Dunmisk crucible fragment examined in detail has evidence for extensive interaction of primary raw materials within the crucible, including semi-fused primary raw materials; this evidence has not been found in glass-working crucibles. The primary evidence for the glass industry at Dunmisk consists of three fragments which derived from one or more pyramidshaped crucibles, similar to those found at Armagh (Gaskell \& Harper 1984: 146, figure 19, no. 113). The fragments have an opaque yellow layer of debris from the manufacture of glass on 
their inner faces (cf. Craddock in Youngs 1989: 173).

FIGURE $3 \mathrm{~b}$ is a backscattered electron micrograph of part of a polished section through the base of one of the Dunmisk glass-making crucibles which, in FIGURE 3a, has been plotted onto the total optical micrograph of the same section through the crucible base; FIGURE 3a is a mirror image of FIGURE $3 \mathrm{~b}$. Various features can be seen in FiguRE $3 \mathrm{~b}$ :

A the core of the partly-vitrified aluminiumrich siliceous crucible wall,

B a thick layer of material consisting of dark grey silica crystals and layers of 'white' lead-rich glass (of a lead oxide-soda-silica composition with a low tin oxide content) and

C fragments of fully-fused but weathered opaque yellow lead oxide-soda-lime-silica glass opacified with lead-tin oxide.

The layer of clear glass $\mathrm{D}$ adhering to the pointed apex of the crucible is of a lead oxidesoda-lime-silica composition with a trace of tin oxide, and is therefore not a fuel-ash slag which would have distinctly different chemical characteristics. At one point under this glass layer

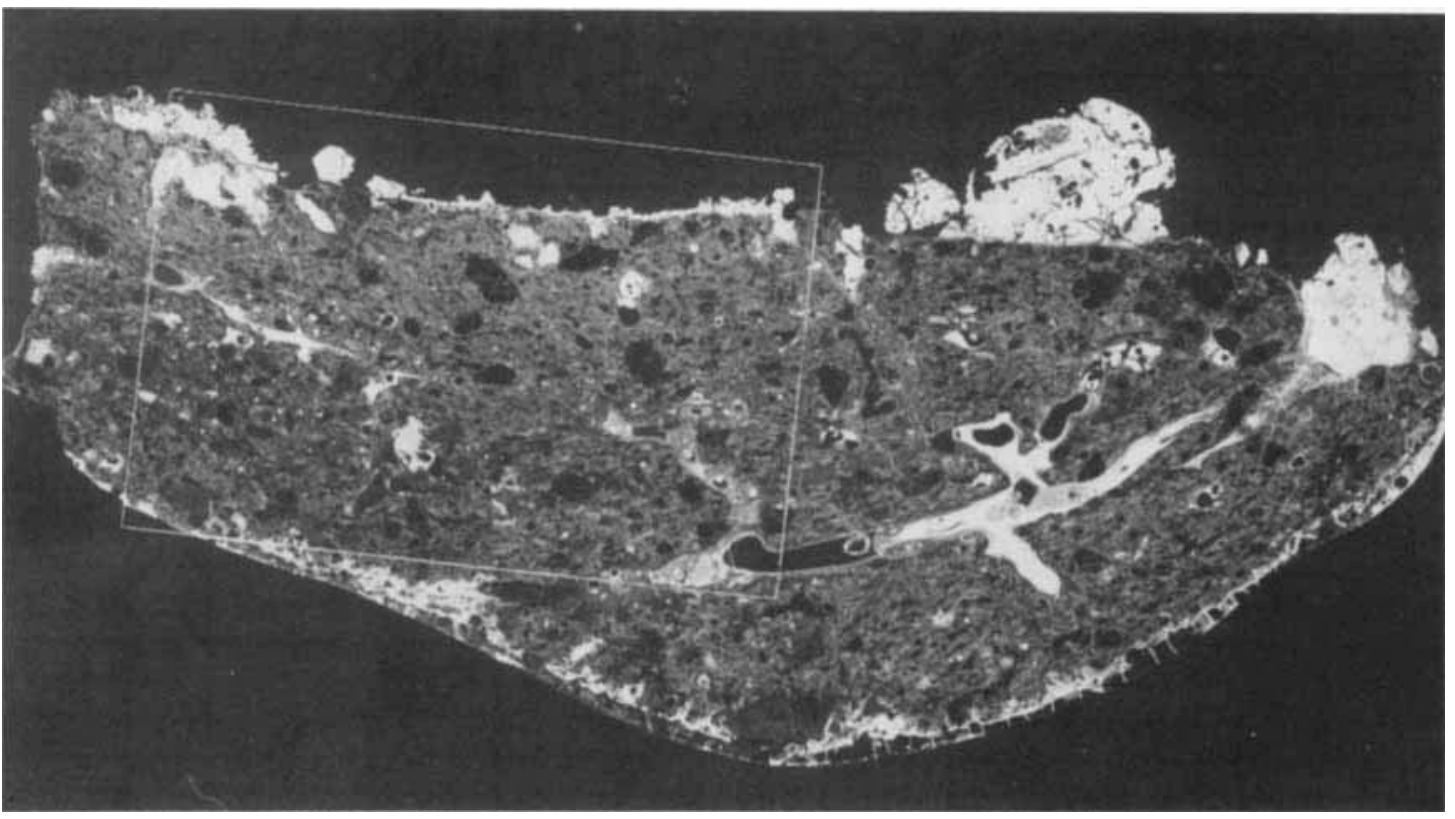

FIGURE 3a. Total optical micrograph of the polished section through a glass-making crucible from Dunmisk, Co. Tyrone with the position of FIGURE 3a marked on it.

(FIgUREs $3 \mathrm{a}$ and $3 \mathrm{~b}$ are a mirror image of each other.)

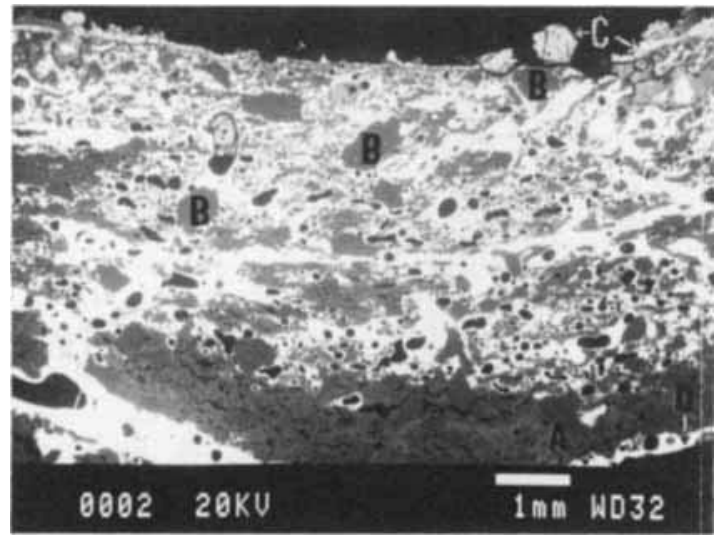

FIGURE 3b. Electron micrograph of part of the polished cross-section through the base of the glass-making crucible from Dunmisk, Co. Tyrone (its position is marked on FIGURE 3a).

A The crucible wall.

B Unreacted silica is present in the lead-rich glass-making debris.

C Fragments of fully-fused, weathered opaque yellow glass.

D Lead-rich glass adhering to the outside of the crucible apex. 
there is a trapped tin oxide crystal which has not dissolved in the clear glass, and probably derives from the melt bubbling over the rim of the crucible, down the sides and accumulating on the base.

Of the other primary raw materials used, much of the sodium oxide has fused with the lead oxide and silica, and, in any case, any uncombined, or partially fritted soda would either have leached out of the environment or boiled off. Another primary raw material, silica, is present as angular particles throughout the partly-fused glass batches. The fourth 'major' component of the yellow glass would, if added as calcium carbonate, break down into calcium oxide and carbon dioxide at a temperature below the melting temperature of the lead oxide in glass and, as a result, would not be found as isolated fragments amongst the debris in the crucible. The weathered fully fused fragments of opaque yellow glass lying on the surface of the material in the crucible are soda-rich.

The crucible was probably used for two episodes of glass melting: the evidence for the two lies above a roughly horizontal line of 'white' lead-rich glass (in FIGURE 3b) which divides the layers of debris roughly into two. Starting at the bottom of FIGURE $3 \mathrm{~b}$, the lowest (black and pale grey zone) is part of the aluminium-rich crucible core, the zone above it is probably where the lead-rich glass has comprehensively interacted with the crucible fabric and is characterized by a high density of gas bubbles, mainly small silica particles (dark grey) and pools of lead-rich glass (appearing 'white' in the atomic contrast of FIGURE $3 b$ ). The upper section (above the horizontal line of lead-rich glass) is considered to be the debris of the first episode of glass melting and is characterized by larger and more angular (grey) silica particles and fewer gas bubbles than the zone below it; this upper section is also suffused with soda-lead oxide-silica glass. The glassmaking debris is suffused with lead-rich glass because lead-rich glass has a relatively low melting-point and because it is highly mobile. Some of the silica in the upper layer has not even started to melt into the lead-rich glass judging from its angularity, probably because of the larger particle sizes involved; smaller silica particles have done so. There is evidently a heterogeneous mixture of raw material particle sizes involved. On the surface of the crucible is the evidence for the second melting episode: particles of fully fused, partly weathered, opaque lead-tin oxide yellow glass.

The evidence for semi-fused glass in conjunction with primary raw materials (silica and tin oxide) has not been reported before in an early medieval European context; it is both unusual and exceptional evidence. One would not expect to find glass of a transitional composition (between a combination of some of the raw materials and the established chemical composition for opaque yellow Irish Early Christian glass) present together with fully fused glass and unfused primary raw materials such as silica and tin oxide in a glass-working environment since these result from making glass; the lack of detected copper in any of the components confirms that the tin oxide detected was not being used to make copper alloys. The evidence is so unusual we do not have anything to compare with it and, at the very least, is evidence for the addition of primary raw materials to an already melted glass and can thus be described as glass-making.

The lead-rich glass of transitional composition mixed with silica could be described as a frit; the next stage in the process would be to remove the frit, grind it down to fine particles and remove the impurities (in this case, unfused silica). This would have been a relatively low temperature process $\left(c .550^{\circ} \mathrm{C}-650^{\circ} \mathrm{C}\right.$ for leadrich glass) and would certainly lead to the pools of lead-rich glass seen in section in FIGURE $3 \mathrm{~b}$. The remnant thin layer of opaque yellow glass on the surface of the glass-making debris, some of which is badly weathered, represents the fusion of sufficiently crushed primary raw materials to promote full fusion when heated together; this is more evidence for a heterogeneous melt.

The glass being produced at Dunmisk was a high lead oxide (PbO)-soda $\left(\mathrm{Na}_{2} \mathrm{O}\right)$-lime $(\mathrm{CaO})$ silica $\left(\mathrm{SiO}_{2}\right)$ opaque yellow glass. It was rendered opaque with crystals of lead-tin oxide (' $\mathrm{PbSnO}_{3}$ '), an opacifier which first appeared in ancient glass technology in Celtic Europe in the 2nd century BC. (Henderson \& Warren 1983; Henderson 1989b: 50-52). As such, it can be seen as the survival of a Celtic technology rather than a continuation of Roman technology. This is an important point, since the received wisdom is that early medieval glass-production was based mainly on recycled Roman glass 
until the 9th-10th centuries, though we know at that time that potassium oxide started to be used as an important primary alkali (Evison 1990: 223); the manufacture of opaque yellow glass in the Celtic (late Iron Age) tradition in early medieval Ireland emphasizes the importance of the Dunmisk evidence. This yellow glass was not, as believed for some time, first introduced in the 4th century AD (Turner \& Rooksby 1961 : $2-3$ ) as part of late Roman glass technology.

In Ireland, lead-tin opacified yellow glass like that made at Dunmisk was used to decorate a variety of glass bead categories, some diagnostically Early Christian. The colour was not used in millefiori glass, as found at Dunmisk (Henderson 1988a: 116-17, figure 1 and table 1), but was used in millefiori from, for example, Garranes ringfort, Co. Cork (Ó Ríordáin 1941-2: figure 15) and in blue and yellow bichrome cable from Scotch Street, Armagh (Lynn 1988). The chemical composition of the yellow glass in the Scotch Street rods is of the type being made at Dunmisk (Henderson unpublished data). Opaque yellow glass is considered to have been introduced for enamelling soon after $A D 600$ (Youngs 1989: 21).

\section{Glass-making and the glass industry in Early Christian Ireland}

The industrial evidence and finished artefacts show a range of uses for vitreous materials in Early Christian Ireland. But was glass made elsewhere in Early Christian Ireland that was re-melted and worked at various locations (TABLE 2)?

The level of sophistication attained in the manufacture of glass bosses/studs, including one with a gold foil inlay (Lynn 1989: 194) and the enamelling and millefiori inlay of metalwork (such as attained on the Derrynaflan paten, Co. Tipperary: Ryan 1987: 66, 68, plate Ia, plate II; Haseloff 1990: 166, plate 128a, 128b, 130) by the 8th and 9 th centuries AD was very high. The use of enamel and millefiori inlay to decorate metalwork would have involved a close consideration of the relative properties of the two materials at high temperatures (ultimately determined by their chemical compositions), and of a means of attaching the glass to the metal surface. A knowledge of the softening and melting temperatures of the glass, the length of time necessary to soften and melt it, and the quantity of fuel needed to achieve an appropriate temperature would have been refined through practice, perhaps initially by heating glass in crucibles and concentrating heat on metal surfaces with the aid of a blow-pipe.

Given this level of sophistication in the Early Christian glass- and enamel-working industries, evidence for glass-making is not surprising and one can expect to find it elsewhere. Thus a proportion of the glass used in Early Christian Ireland was actually made there, rather than merely imported as cullet or glass blocks, though this does not exclude the possibility of such importation as well. This consideration of the evidence for glass-making prompts a range of further, related, questions:

1 Where were the production centres for bichrome cables ('reticella' rods) used in Early Christian Ireland and to decorate Anglo-Saxon vessels?

Two 8th-century Scandinavian centres of production, at Ribe, Jutland (Bencard et al. 1979; Näsman 1984: 76) and Åhus, Scania (Callmer 1984) and a third possible 8th-century site at Barking, Essex (Evison et al. in preparation) are known, so it is evident that they were made in a number of places (Evison 1983: 92). However, was the glass used to make Irish glass bichrome cables originally fused specially for that purpose, or was recycled (?Merovingian vessel) glass used? The relatively small volume of vessel glass from Early Christian Irish contexts (c. 50 vessel fragments: Bourke 1987) suggests that the latter interpretation is unlikely.

2 What proportion of the glass used in Early Christian Ireland was recycled Roman glass?

3 Was recycled Roman glass used in the manufacture of millefiori ? How does the composition of Roman millefiori relate to that found in Early Christian Ireland and how was it introduced (Henry 1947: 39)?

4 Did metal production and metal decoration occur at the same place, as may have occurred at Dunmisk?

5 Was there a hierarchy of sites (and/or artisans) involved in making glass or enamelled artefacts, and in relation to other industries? 


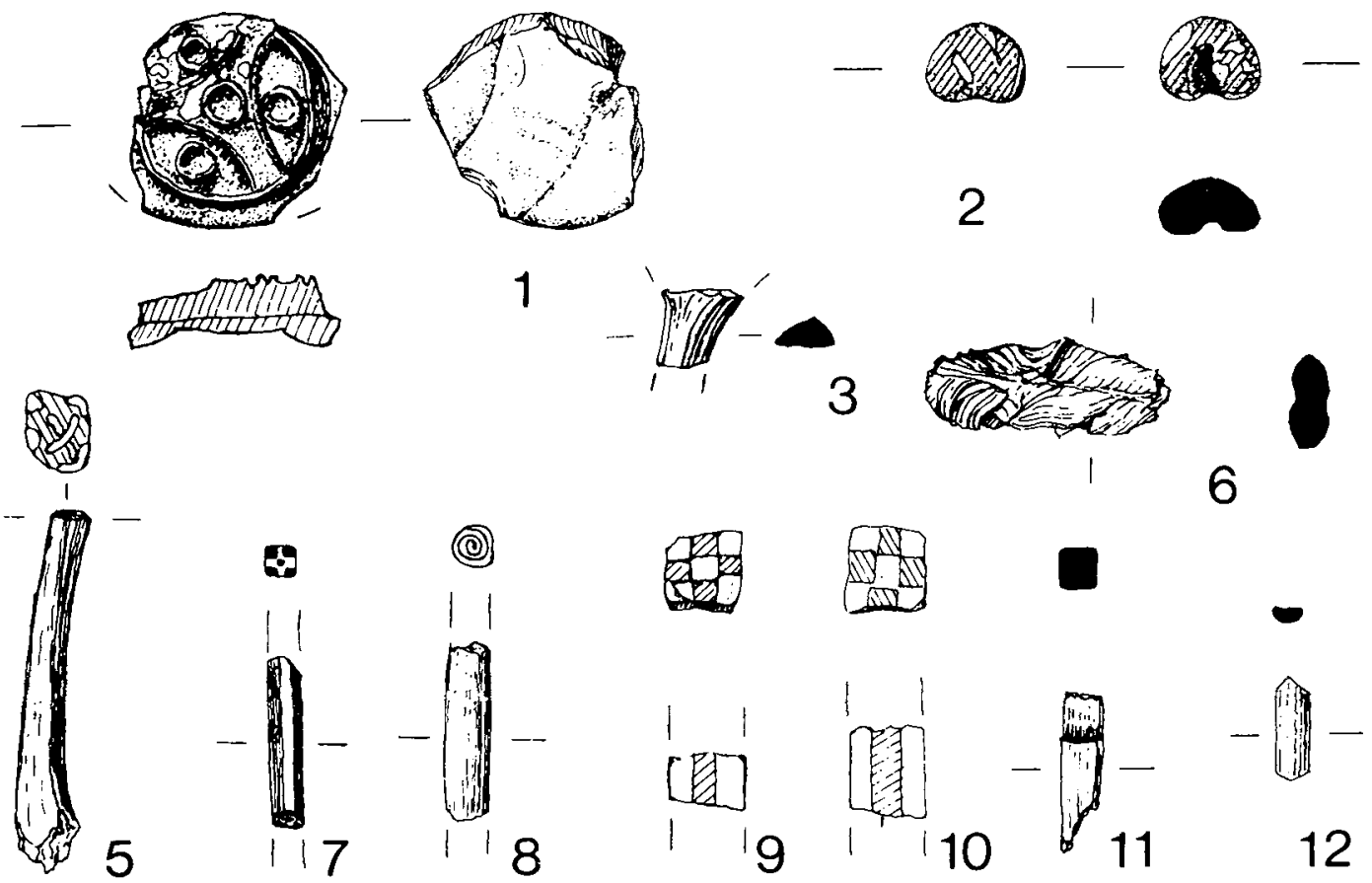

FIGURE 4. Objects of glass from Dunmisk.

1 Remnants of translucent pale blue glass stud.

2 Lump of translucent blue glass with streaks of opaque white glass running through it.

3 Fragment of translucent blue rod (probably resulting from bead-making).

4 (Not illustrated.) Four fragments of translucent green glass full of impurities resulting from glassworking.

5 Translucent blue ribbed rod with longitudinal streaks of opaque white glass. A possible failed cable.

6 Remnants from the production of a cable bead.

7 Section of a translucent blue and opaque white millefiori rod.

8 Section of a translucent blue and opaque white rod, made into a 'Swiss roll'.

9 Short section of a translucent blue and opaque white millefiori rod.

10 Short section of a translucent blue and opaque white millefiori rod.

11 Short section of an opaque pale yellow rod.

12 Short section of a translucent blue rod.

It has been suggested and shown that royal sites were locations for a wide range of industries (Warner 1988: 66). Iron, bronze and glass working took place at Dunmisk, a small monastic community; possible gold-working, a highstatus industry, is evidenced by a bent piece of gold wire at Moynagh Lough, Co. Meath (Bradley in Youngs 1989: 209), presumably not a royal site though its status needs to be demonstrated; the picture is therefore complex. The use of exotic raw materials and the scale of production are relevant to an assessment of the importance of an industry to particular sites; in Early Christian Ireland industries appear to be organized on a small localized scale, considered by Scott (1990: 96-7) not to have been linked directly to the centres and territories associated with kingships. The distribution of materials used in Early Christian vitreous industries is compatible with either widespread communications between specialized industrial centres, or with mobile artisans taking technical knowledge and materials with them.

These questions have been, and are being, closely considered as part of a large-scale analytical programme of vitreous materials from early medieval Ireland, Britain, the Low Countries, Scandinavia and Italy by one of us $(\mathrm{JH})$. In respect of recycling, it has been found that Irish 
Early Christian glass is compositionally distinct from some Roman vessel glass (Henderson 1988b), though, as mentioned above, red-brown glass made in the Roman tradition was used for bead decoration in Early Christian Ireland. Relationships between chemical compositions and artefact type (vessel, bead or armlet matrix/ decoration, stud, metal enamel, millefiori glass, bichrome cable and crucible glass) are critical for building models of Irish industries involving vitreous materials. Evidence for coincidence of metal production and decoration on

\section{References}

BALL, V. \& M. STOKES. 1893. On a block of red glass said to have been found at Tara Hill, Transactions of the Royal Irish Academy 30: 277-93.

BenCARD, M., K. AMbrosiani, L.B. JøRGENSEN, H.B. MADSEN, I. NIELSEN \& U. NÄSMAN. 1979. Wikingerzeitliches Handwerk in Ribe, eine Übersicht, Acta Archaeologica 49: 113-138.

BENCARD, M. \& L.B. JøRGENSEN. 1990. The foundations of Ribe, Antiquity 64: 576-83.

BIEK, L. \& J. BAYLEY. 1979. Glass and other vitreous materials, World Archaeology 11(1): 1-25.

BIMSON, M. 1978. Coloured glass and millefiori in the Sutton Hoo ship burial, Annales du $7^{\mathrm{e}}$ Congrès International d'Etude Historique du Verre, Berlin-Leipzig 1977, Liège 1978, 427-33.

1983. Aspects of the technology of glass and copper alloys. A. Coloured glass and millefiori in the Sutton Hoo grave deposit, in R.L.S. BruceMitford (ed. A. Care Evans), The Sutton Hoo Ship Burial 3: 924-44. London: British Museum Publications.

1987. Opaque red glass: a review of previous studies, in M. Bimson \& I.C. Freestone (ed.), Early Vitreous materials: 165-72. London: British Museum Research Laboratory. British Museum occasional paper 56 .

BOURKE, E. 1987. Glass vessels in Ireland c. 100-1400 $A D$. M.A. thesis, University College, Dublin.

BRADLEY, J. 1984. Excavations at Moynagh Lough, Co. Meath 1982-3: Interim report, Riocht na Midhe $7(3): 86-93$.

Callmer, J. 1984. Recent work at Ahus: problems and observations, Offa 41: 63-75.

Callmer, J. \& J. Henderson. 1991. Glass-working at Ahus, southern Sweden (eighth century AD), Proceedings of the 5th Nordic Conference on the Application of Scientific Methods in Archaeology, 20-24 September 1990. Stockholm.

EvISON, V. 1983. Some distinctive glass vessels of the post-Roman period, Journal of Glass Studies 25: 87-93.

1990. Red marbled glass, Roman to Carolingian, the same site must rely heavily on the scientific excavation of industrial sites, and evidence for site hierarchy on the interpretation of history and archaeology.

Acknowledgements. The authors are grateful to Mavis Bimson and Arthur MacGregor for reading through this paper and commenting on it; the opinions expressed are almost entirely those of the authors. Some of the scientific results used in this paper were produced by JH while a Post-doctoral Fellow at Oxford University, funded by SERC and the Leverhulme Trust.

Annales du $11^{\mathrm{e}}$ Congrès de l'Association Internationale pour l'Histoire du Verre, Bâle 1988: 217-28. Amsterdam: A.I.H.V.

Evison, V., J. HENDERSON \& M. HEYwORTH. In preparation. The glass-working evidence from Barking Abbey, Essex.

GAM, T. 1991. Glasperlefremstilling i yngre jernalder og vikingetid, Exsperimentel Arkaeologi 1: $154-76$.

GASKELL, C.B. \& A.E.T. HARPER. 1984. Excavations on Cathedral Hill, Armagh, 1968, Ulster Journal of Archaeology 47: 109-61.

GraHam-CAmPBell, J. 1981. The bell and the moulds, in R. Reece, Excavations in Iona 1964 to 1974: 23-5. London: Institute of Archaeology. Occasional Publications 5.

HASElofF, G. 1990. Email im Fruhen Mittelalter. Marburg: Hitzeroth.

HENCKEN, H. O'N. 1950-1. Lagore Crannog: an Irish royal residence of the 7 th to 10 th centuries $A D$, Proceedings of the Royal Irish Academy 53C: 1-237.

HENDERSON, J. 1984. The glass in R. Ivens Movilla Abbey, Newtownards, County Down: excavations 1981, Ulster Journal of Archaeology 47: 98-101.

1988a. The Nature of the early Christian glass industry in Ireland: some evidence from Dunmisk Fort, Co. Tyrone, Ulster Journal of Archaeology 51: 115-26.

1988b. A technical investigation of early Irish glass and glass-making practices, in E.V. Sayre, P.B. Vandiver, J. Druzik \& C. Stevenson (ed.), Materials Issues in Art and Archaeology: 141-6. Pittsburgh: Materials Research Society. Symposium Proceedings 123.

1989a. The evidence for regional production of Iron Age Glass in Britain, in M. Feugere (ed.) Le verre préromain en europe occidentale: chapter 4. Montagnac: Librairie Archéologique.

1989b. The scientific analysis of ancient glass and its archaeological interpretation, in J. Henderson (ed.), Scientific analysis in archaeology and its 
interpretation: 30-62. Oxford: Oxford University Committee for Archaeology. Monograph 19.

1990. Chemical and structural analysis of Roman enamels from Britain, Archaeometry '90: 285-94. Proceedings of the 1990 Archaeometry Conference, Heidelberg.

HENDERSON, J. \& S.E. WARREN. 1983. Analysis of Prehistoric lead glass, in Proceedings of the 22nd Symposium on Archaeometry: 168-80. Bradford: University of Bradford.

HENRY, F. 1947. Irish Art in the Early Christian period. 2nd edition. London: Methuen.

HOPE-TAYLOR, B. 1977. Yeavering: an Anglo-British centre of early Northumbria. London: HMSO. DoE Archaeological Report 7.

IvENS, R.J. In press. Excavations at Dunmisk Fort, Co. Tyrone, 1984-86, Ulster Journal of Archaeology 52 (1989).

LYNN, C. 1988. Excavations at 46-48 Scotch Street, Armagh, 1979-80, Ulster Journal of Archaeology 51: 69-84.

1989. Deer Park Farms, Current Archaeology 113: 193-8.

NÄSMAN, U. 1986. Vendel period glass from EketorpII, Oland, Sweden, Acta Archaeologica 55: 55-116.

O'Kelly, M.J. 1962. Two ring-forts at Garryduff, Co. Cork, Proceedings of the Royal Irish Academy 63: 17-125.

Ó RIORDÁIN, S.P. 1941-2. The excavation of a large earthen ringfort at Garranes, Co. Cork, Proceedings of the Royal Irish Academy 47C: 77-150.

1949. Lough Gur excavations: Carraig Aille and the 'Spectacles', Proceedings of the Royal Irish Academy 52C: 39-111.

RYAN, M. 1987. Some aspects of sequence and style in the metal work of eighth- and ninth-century Ireland, in M. Ryan (ed.), Ireland and insular art $A D$ 500-1200: 66-74. Dublin: Royal Irish Academy.

SCOTT, B.G. 1990. Early Irish Ironworking. Belfast: Ulster Museum.

SCOTT, E.M., M.S. BAXTER \& T.C. AItCHuSON. 1983. A comparative view of calibration, in B.S. Ottaway (ed.), Archaeology, dendrochronology and the radiocarbon calibration curve: 37-41. Edinburgh: Edinburgh University Press. University of Edinburgh Occasional Paper 9.

Stuiver, M. \& G.W. Pearson. 1986. High-precision calibration of the radiocarbon time-scale, Radiocarbon 28(2B): 805-36.

TURNER, W.E.S. \& H.P. ROOKSBY. 1961. Further histori$\mathrm{cal}$ studies based on X-ray diffraction methods of the reagents employed in making opal and opaque glasses, Jahrbuch des RömischGermanischen Zentralmuseums Mainz 8: 1-6.

WAKEMAN, W.F. 1889. On the crannog and antiquities of Lisnacroghera near Broughshane, Co. Antrim, Journal of the Royal Historical and Archaeological Society of Ireland 9: 98-107.

WARNER, R.B. 1988. The archaeology of early Irish kingship, in S. Driscoll \& M. Nieke (ed.) Power and politics in early medieval Britain and Ireland: 47-68. Edinburgh: Edinburgh University Press.

In press. A proposed adjustment for the 'old-wood effect', PACT (Journal of the European Science Foundation).

YounGs, S. (ed.). 1989. 'The work of angels': masterpieces of Celtic metalwork, 6th-9th centuries AD. London: British Museum Publications. 